MH Egészségügyi Központ Védelemegészségügyi Igazgatóság, Egészségfejlesztési Osztály

\title{
Katonai egészségprofil a Magyar Honvédségben
}

\author{
Dr. Novák Attila százados, $\mathrm{PhD}$, \\ Dr. Sótér Andrea alezredes, $\mathrm{PhD}$
}

Kulcsszavak: megelözés, egészségmagatartás, klaszterelemzés, katonai egészség profil

A krónikus nemfertőző megbetegedések korát élve - a hadseregben is - az egészség megtartására, a betegségek megelözésére irányul a figyelem. Az egészségi állapotot - amely a hosszú távú bevethetőség alappillére, számos tényező közül leginkább az életmód határozza meg és az egyén egészségmagatartási tényezőinek elemzésével vizsgálható. Kutatásunkat a Magyar Honvédség katonai állományában, a foglalkozás-egészségügyi szürővizsgálat keretében felvett prevenciós adatlap adatait felhasználva végeztük. Arra kerestük a választ, hogy milyen egészségmagatartási mintázatok jellemzőek a katonákra, és ezen mintázatok között vannak-e szignifikánsan megkülönböztethető homogén csoportok, ún. klaszterek. Elsőként a kiválasztott 24 objektív és szubjektív egészségmagatartási mutatóhoz értékskálákat rendeltünk, majd hierarchikus klaszteranalízist végeztünk. Ennek eredményeként 16 olyan egészségmagatartási szempontból homogén egészségprofilt találtunk, amely csoportok beazonosítása alapjául szolgálhat a prevenciós programok további fejlesztéséhez és ezáltal az állomány egészségi állapotának javításához.

Tudjuk, tudhatjuk-e pontosan, hogy milyen paraméterekkel írható le az egészség szempontjából a haderőt alkotó „katona", ami a hosszútávú alkalmazhatóság, bevethetőség alappillére? Számos genetikai, fizikai- és szociális környezeti, életmódbeli stb. tényező befolyásolja az egészségi állapotunkat, mely tényezők kutatása kiemelt jelentőségü napjainkban, amikor a haláloki statisztikákat a krónikus nem fertőző megbetegedések vezetik. Az egyén életmódjából adódó (táplálkozás, testmozgás, alvás, stresszkezelés, társas kapcsolatok minősége), az egészségi állapotára pozitív és negatív hatások vizsgálatára számos kutatást végeztek $[1,2,3,4]$ amely mind az életmód pozitív irányú megváltoztatására, ezzel együtt a betegségek kialakulásának megelőzésre hívták fel a figyelmet. Vizsgála- 
tunkban arra kerestük a választ, hogy az egészségmagatartási mintázatok között vannak-e szignifikánsan megkülönböztethető homogén csoportok, ún. klaszterek.

\section{Vizsgálati minta és eszköz}

Keresztmetszeti vizsgálatunkban a 20112015 között a foglalkozás-egészségügyi szürővizsgálaton megjelent katonák vettek részt $(\mathrm{n}=5475)$. A vizsgálati minta 19\%-a 18-30 év közötti, 49\%-át a 31-40 év közötti korcsoport alkotta, 41-45 év között a minta 18\%-a, 46-50 év között $9 \%$ és 51 év felett $4 \%$ volt. Az elemzésbe vont faktorok egyik részét ún. „kemény” változók (objektív mutatók) alkották: életkor, nem, diagnosztizált megbetegedés (BNO), testtömeg index (BMI). Másik részük egyéni önjellemzésből származó, ún. „puha” változó (szubjektív mutató) volt: étkezési szokások, dohányzási státusz, mindennapi fizikai aktivitás, sportolási szokások, pszichoszomatikus tünetek jelenléte, mentális állóképesség (MÁQ) és alvási apnoé státusza. Az egyes faktorokra adható válaszlehetőségeket egy lineáris skálán pontoztuk, a 24 faktor alapján elérhető minimális pontszám $-47,5$, a maximális 48,5 pont volt. Végső lépésként az adatok klaszteranalízisével megalkottuk a mintára jellemző egészségprofilokat.

\section{Az objektív mutatók kategória értékeinek meghatározása}

Életkor [-2; 0 pont]: 30 év alatt 0 pont; 30-40 év között -1 pont; 40 év felett -2 pont. Nem [-1; 0 pont]: férfi -1 pont; nő 0 pont. Diagnosztizált megbetegedés (orvos által megállapított, krónikus nem fertőző betegség) [-9; 0 pont]: egy betegség -3 pont; két betegség -6; kettőnél több megbetegedés -9 pont. Testtömeg-index (TTI) [-5; 1 pont] vonatkozásában $5 \mathrm{ka}-$ tegória alapján [5].

\section{Szubjektív megítélésen alapuló mutatók kategóriaértékeinek meghatározása}

Táplálkozás [-12,5; 13,5 pont]: a föétkezések (reggeli, ebéd, vacsora) rendszerességét, valamint az étrend minőségi öszszetételét vizsgálatuk. A rendszeresség vonatkozásában a munkanapokon történő fóétkezések heti gyakoriságát elemeztük és értékeltük -2,5 és +3 közötti skálán $[6,7]$.

A táplálkozás minőségi faktorainak vizsgálatánál egyrészt a zöldség-, gyümölcs-, tejtermék- és gabonafogyasztás étrendben való megjelenési gyakoriságát vizsgáltuk és értékeltük egy -6 és +5 közötti skálán. Másrészt vizsgáltuk a húsfélék, gabonafélék és zsiradékok típusának preferenciáját, amit egy -2 és +3.5 közötti skálán mértünk [8].

Dohányzási státusz [-5; 0 pont]: vonatkozásában a legalacsonyabb pontot (-5 pont) a dohányzók kapták, -3 pontot kaptak azok, akik leszoktak a dohányzásról és 0 pontot azok, akik soha nem dohányoztak.

Fizikai aktivitás [-5; 22 pont]: A napi fizikai aktivitás vonatkozásában a közlekedési szokásokat és a hetente sportolással töltött időt, valamint a sporttevékenység intenzitását vizsgáltuk. Előbbi esetében a közlekedésben elönyben részesített módot (gyalogosan, kerékpárral, vagy gépkocsival esetleg tömegközlekedéssel) és a munkahely lakóhely között megtett időt mértük $[10,11,12]$.

Alvás [-4; 3 pont]: azok, akik fáradtan ébredtek - 2 pontot kaptak, a frissen ébredők +3 pontot. Berlin kérdőív segítségével vizsgálatuk az alvási apnoe (OSAS) előfordulását: <6 pont esetén 0 pontot 
adtunk, 6-8 pont között -1 pontot és $>8$ pontnál -2 pontot kaptak a válaszadók $[13,14]$.

Mentális állóképesség (MÁQ) [-3;8 pont]: A Magyar Honvédségben használt MÁQ teszt a pszichológiai reziliencia mértékét méri az egyénre jellemző automatikus gondolkodási minták hatékonyságán keresztül. A pontozás során ezt a skálát transzformáltuk át egy -3 ; +8 közötti skálára, úgy hogy a MÁQ pontszámát. megszoroztuk 11/80 és kivontunk belöle 5,75-t $[15,16]$.

Pszichoszomatikus tünetek $[-6 ; 0$ pont]: a leggyakoribb pszichoszomatikus tünetek (hátfájás, fejfájás, gyomor és hasfájás, rosszkedv, ingerlékenység, idegesség, és fáradtság) gyakoriságát vizsgáltuk és értékeltük.

A hátfájást külön pontoztuk a fenti kategóriák alapján, tekintettel arra, hogy korábbi kutatásunkban a pszichoszomatikus tünetek közül a hátfájás gyakorisága volt a legnagyobb hatással a betegségek megjelenésére. A többi tünetre adott pontszámokat összeadtuk és elosztottuk hattal $[17,18]$.

\section{Eredmények}

A hierarchikus klaszteranalízis a fenti változók alapján 16 egymástól megkülönböztethető homogén csoportot (klasztert) eredményezett. A vizsgálat alá vont 24 faktor alapján az elérhető minimális pontszám $-47,5$, a maximális $+48,5$ pont volt. A legalacsonyabb elért pontérték 3,1, a legmagasabb 26,2 pont volt. A legkevesebb pontot - a minta 1,8\%-a - a legmagasabb átlagéletkorral $(43,5 \pm 7,2$ év) rendelkező klaszter érte el, amelyben a nők a legnagyobb arányban (46\%) képviseltették magukat. A két legmagasabb pontszámot elérő klaszter - a minta 2,9\%-a és 5,5\%-a - a két legfiatalabb $(33,7 \pm 7,1$ és $34,3 \pm 7,9$ év) átlagéletkorral rendelkező csoport volt.

Táplálkozás: A munkanapokon történő főétkezések rendszerességének vonatkozásában az egyes klaszterek között jelentős eltérést nem találtunk, a minta túlnyomó része rendszeresen reggelizik (76\%), ebédel (86\%) és vacsorázik (85\%). A gabonafélék közül a minta túlnyomó része (77\%) barna- vagy teljesőrlésủ lisztből készült terméket fogyaszt. A húsfogyasztás vonatkozásában alacsony a csak fehér húst fogyasztók aránya (32\%), föként a vörös és fehér húst vegyesen fogyasztók vannak többségben (63\%). A kizárólag fehér húst fogyasztók legnagyobb arányban az összpontszám tekintetében első helyre rangsorolt 9-es klaszterben fordultak elö (40\%), míg a legkisebb arányban az utolsó előtti helyen álló 5-ös számú klaszterben (23\%) voltak.

Fizikai aktivitás: A közlekedési szokásokat tekintve a vizsgálat alá vont katonák 43\%-a gépkocsival - közel 34\%-a gyalog vagy kerékpárral jár a munkahelyére. Öt csoport $(2,6,7,8,14$,) tagjai szinte kizárólag gépkocsival jártak munkába. Egy klaszter volt (10.) a mintában, akik közül mindenki gyalog vagy kerékpárral közlekedett. A vizsgált katonák közel 7 százaléka az utazás során több mint egy órát tölt a gépkocsijában. Hat klaszterben $(4,9,10,11,12,13)$ nem használnak gépkocsit a munkába járáshoz. Sportolási szokások tekintetében a 16 klaszter közül csak egy (5.) volt, amelyeket kizárólag azok alkották, akik hetente kevesebb sporttevékenységet folytattak. Ezzel ellentétben négy olyan csoport $(2,7,9$, 12) volt, ahol mindenki a lehetö legtöbbet sportolta. A mintában szereplök több mint 51\%-a kielégítő (hetente 2-3 alkalommal, minimum 30 perces közepes vagy annál nagyobb intenzitású) spor- 
tolási szokásokkal rendelkezett. A katonák 31\%-a naponta legalább 30 percet sportolt. A sportolásra vonatkozó pontszámok kerültek kiszámolásra úgy, hogy valamennyi klaszter esetében megvizsgáltuk, a sportolási kategóriákba (ti. napi rendszeresség, heti 2-3 alkalom, heti rendszeresség, ritkábban) esők számát, az elemszámot megszoroztuk az egyes kategóriákhoz rendelt pontszámokkal, majd a kapott eredményt elosztottuk a klaszter létszámával. A minta 87\%a sporttevékenységét pulzus kontrollal végzi, és a sportolást követően több mint 81\%-a közepesen fárad el.

Dohányzási státusz: A minta 47\%-a soha nem dohányzott. Öt klaszterbe (3, $6,7,9,11)$, csak olyanok kerültek, akik soha nem dohányoztak és öt klaszterbe $(1,5,8,10,15)$ olyanok, akik jelenleg is dohányoznak. A dohányzók és a leszokottak aránya közel azonos volt a mintában ( $27 \%$ vs. $26 \%$ ). A dohányosok aránya a 13-as klaszterben volt a legmagasabb.

Alvás: Frissen ébredők alkották teljes egészében $(100 \%)$ a $2,3,4$ a $6,8,9$ és a 11, 12, 13, 14 illetve a 16 számú klasztert. A 7 -es és a 10-es klasztert közel teljes egészében (99\%) frissen ébredők alkották, míg az 5-ös számú csoportot 90\%-ban azok alkották, akik nem fáradtan ébredtek. Az 1-es és a 15-ös klaszterben senki nem volt ( $0 \%)$, aki frissen, nem fáradtan ébredt volna. Az alvási apnoe tekintetében a minta 91,7\%-ban kockázat nélküli, 6 pont vagy az alatti értéket adott. A legmagasabb számban (98\%) a 13-as a legalacsonyabb arányban (68\%) az 1-es számú klaszterben fordultak elö.

Pszichoszomatikus tünetek: A pszichoszomatikus tünetek (hátfájás, fejfájás, gyomor- és hasfájás, rosszkedv, ingerlékenység, idegesség, valamint a fáradtság) eredményénél az elérhető pontha- tárok mínusz 3 és 0 pont közé eshettek. A minta átlaga $-0,341$ pont volt. A legmagasabb átlagértéket $(-0,182 \pm 0,2$ pont $)$ elérő klaszter a 9-es számú, míg a legalacsonyabb értéket $(-0,906 \pm 0,6$ pont) elérő az 1-es klaszter lett.

A hátfájást, mint tünetet külön kezeltük tekintettel arra, hogy korábbi kutatásunkban a pszichoszomatikus tünetek közül a hátfájás gyakorisága volt a legnagyobb hatással a betegségek megjelenésére [19]. A vizsgálat alapján a minta átlagosan $61,2 \%$ ban tartalmazott olyan katonákat, akiknél nagyon ritkán, vagy soha nem fordult elő hátfájás, mint tünet. Ezek a katonák legmagasabb arányban (79\%) a 7-es számú, a legalacsonyabb arányban (27\%) az 1-es számú klaszterben voltak.

Mentális állóképesség (MÁQ): A MÁQ tekintetében 2,21 pont lett az átlaga a mintának azok után, hogy skálatranszformációt hajtottunk végre. Ennek következtében a szerezhetô ponthatárok $-3 ;+8$ közé eshettek. A legalacsonyabb átlagértéket (1,76 $\pm 1,0$ pont) az 1-es számú, míg a legmagasabbat $(2,54 \pm 1,0$ pont $)$ a 9 -es számú klaszter érte el.

Összegzett eredményeinket az I. és II. és a III. táblázat mutatja.

\section{Konklúzió}

Véleményünk szerint az egészségmagatartási szokások hasonlóságainak és különbözőségeinek figyelembe vételével csoportokra bontható a Magyar Honvédség állománya. Az így kapott klaszterek egészségfejlesztési intervenciós lehetőségei és eredményének nyomon követése könnyebbé válhat. Számos klaszterben láttuk, hogy a csoport tagjai az egészségkárósító attitüdök ellenére a még betegséggel nem rendelkezők csoportjába kerültek. Ezeknek a klasztereknek a tagjai a kellő intervencióval 
I. táblázat. Vizsgált objektív mutatók klaszterenkénti értékei (N=5475).

A zárójelekben lévő számok a rangsort jelölik.

\begin{tabular}{|c|c|c|c|c|c|c|c|c|c|c|}
\hline \multirow{2}{*}{$\begin{array}{c}\text { Klasz- } \\
\text { ter }\end{array}$} & \multirow{2}{*}{$\begin{array}{c}\text { Rangsor } \\
\left({ }^{*} p \leq 0,05\right)\end{array}$} & \multirow{2}{*}{$\begin{array}{l}\text { Pont- } \\
\text { érték }\end{array}$} & \multirow{2}{*}{ Életkor } & \multirow{2}{*}{ Nők (\%) } & \multirow{2}{*}{$\begin{array}{c}\text { Betegség } \\
(\%)\end{array}$} & \multicolumn{5}{|c|}{ TTI kategóriák (\%) } \\
\hline & & & & & & 1. & 2. & 3. & 4. & 5. \\
\hline 1 & 16. & 3,1 & $43,5 \pm 7,2$ & 46 & 100 & 1 & $43 !$ & 22 & 6 & 28 \\
\hline 2 & 8.* & 17,3 & $34,4 \pm 6,7$ & 7 & 0 & 1 & 51 & $13 !$ & $2 !$ & 33 \\
\hline 3 & 12. & 12,7 & $41,6 \pm 6,9$ & 34 & 100 & 0 & 50 & 18 & 6 & 25 \\
\hline 4 & 9.* & 13,6 & $37,3 \pm 6,8$ & 13 & 0 & 0 & 79 & 19 & $2 !$ & 0 \\
\hline 5 & $15 .^{*}$ & 4,6 & $38,5 \pm 7,4$ & 25 & 21 & 2 & $41 !$ & 18 & $4 !$ & $35 !$ \\
\hline 6 & $6 .^{*}$ & 18,6 & $37,2 \pm 6,3$ & 24 & 0 & 0 & 52 & $10 !$ & 1 & $37 !$ \\
\hline 7 & 4. & 22,4 & $34,7 \pm 6,9$ & 12 & 0 & 0 & 52 & $8 !$ & 1 & $40 !$ \\
\hline 8 & 11. & 12,9 & $37,5 \pm 6,4$ & 15 & 0 & 0 & 51 & 20 & $2 !$ & 27 \\
\hline 9 & $1 .^{*}$ & 26,2 & $34,3 \pm 7,9$ & 15 & 0 & 2 & $46 !$ & $8 !$ & 1 & $43 !$ \\
\hline 10 & $2 .^{*}$ & 24,8 & $33,4 \pm 7,1$ & 9 & $1 !$ & 1 & 53 & $9 !$ & 1 & $36 !$ \\
\hline 11 & $3 .^{*}$ & 22,5 & $36,5 \pm 7,6$ & 25 & 0 & 1 & $48 !$ & $9 !$ & 0 & $42 !$ \\
\hline 12 & $5 .^{*}$ & 21,5 & $34,4 \pm 7,5$ & 11 & 0 & 2 & $48 !$ & $7 !$ & 1 & $42 !$ \\
\hline 13 & 7. & 18,6 & $35,5 \pm 7,6$ & 29 & 0 & 7 & 0 & 0 & 0 & 93 \\
\hline 14 & $10 .^{*}$ & 13,2 & $35,8 \pm 6,7$ & 18 & 0 & 1 & 50 & $14 !$ & $2 !$ & 32 \\
\hline 15 & 13. & 12,5 & $38,3 \pm 7,0$ & 30 & 0 & 1 & 52 & $10 !$ & 1 & $37 !$ \\
\hline 16 & $14 .^{*}$ & 8,3 & $41,7 \pm 7,0$ & 29 & 100 & 1 & $48 !$ & 18 & 7 & 26 \\
\hline \multicolumn{2}{|c|}{ Átlag } & 15,8 & 36,9 & 21,1 & 15,32 & 1,25 & 47,75 & 12,68 & 2,3 & 35,93 \\
\hline
\end{tabular}

TTI kategóriák:

1. = férfiak esetében $18-19,9 \mathrm{~kg} / \mathrm{m}^{2} \mathrm{között}$, 3. $=30,1-35 \mathrm{~kg} / \mathrm{m}^{2} \mathrm{között}$,

2. = nők esetében $<20 \mathrm{~kg} / \mathrm{m}^{2}$, mindkét nem 4. $=35,1 \mathrm{~kg} / \mathrm{m}^{2}<$, esetében $25,1-30 \mathrm{~kg} / \mathrm{m}^{2}$ között,

5. $=20-25 \mathrm{~kg} / \mathrm{m}^{2}$

II. táblázat. Klaszterenkénti összefoglaló táblázat a táplálkozási szokások szerint (N=5475). A zárójelekben lévö számok a rangsort jelölik.

\begin{tabular}{|c|l|l|l|l|l|l|l|}
\hline \multirow{2}{*}{ Klaszter } & \multicolumn{7}{|c|}{ Táplálkozás minöségi faktorai (\%) } \\
\cline { 2 - 10 } & Zöldség & Gyümölcs & Tejtermék & Gabona & Liszt & Fehér hús & Zsiradék \\
\hline $1(16)$ & $38(10) !$ & $51(8)$ & $41(9)$ & $70(1)$ & $59(4)$ & $36(4)$ & $38(9)$ \\
\hline $2(8)$ & $40(8) !$ & $56(3) !$ & $46(4) !$ & $56(8)$ & $51(9)$ & $30(7)$ & $51(3)$ \\
\hline $3(12)$ & $45(4) !$ & $52(7)$ & $49(2) !$ & $64(3)$ & $61(2)$ & $34(5)$ & $40(8)$ \\
\hline $4(9)$ & $39(9) !$ & $60(2)$ & $51(1) !$ & $56(8)$ & $60(3)$ & $28(8)$ & $51(3)$ \\
\hline $5(15)$ & $29(13)$ & $46(11)$ & $44(6)$ & $56(8)$ & $57(5)$ & $23(10)$ & $57(1)$ \\
\hline $6(6)$ & $44(5) !$ & $52(7)$ & $45(5) !$ & $63(4)$ & $60(3)$ & $34(5)$ & $47(6)$ \\
\hline $7(4)$ & $51(1) !$ & $53(6) !$ & $42(8)$ & $66(2)$ & $59(4)$ & $37(3)$ & $51(3)$ \\
\hline $8(11)$ & $27(14)$ & $54(5) !$ & $46(4) !$ & $42(12)$ & $56(6)$ & $26(9)$ & $46(7)$ \\
\hline $9(1)$ & $48(2) !$ & $49(9)$ & $42(8)$ & $60(6)$ & $59(4)$ & $40(1)$ & $48(5)$ \\
\hline $10(2)$ & $35(12) !$ & $51(8)$ & $46(4) !$ & $49(11)$ & $57(5)$ & $26(9)$ & $47(6)$ \\
\hline $11(3)$ & $43(6) !$ & $61(1)$ & $48(3) !$ & $57(7) !$ & $60(3)$ & $34(5)$ & $48(5)$ \\
\hline $12(5)$ & $41(7) !$ & $52(7)$ & $46(4) !$ & $54(10)$ & $62(1)$ & $33(6)$ & $49(4)$ \\
\hline $13(7)$ & $46(3) !$ & $49(9)$ & $49(2) !$ & $61(5)$ & $54(8)$ & $30(7)$ & $48(5)$ \\
\hline $14(10)$ & $36(11) !$ & $53(6) !$ & $45(5) !$ & $55(9)$ & $55(7)$ & $30(7)$ & $52(2)$ \\
\hline $15(13)$ & $36(11) !$ & $55(4) !$ & $48(3) !$ & $66(2)$ & $55(7)$ & $39(2)$ & $46(7)$ \\
\hline $16(14)$ & $45(4) !$ & $47(10)$ & $43(7)$ & $63(4)$ & $51(9)$ & $37(3)$ & $37(10)$ \\
\hline Átlag & $35.88 !$ & $53.54 !$ & $46.16 !$ & $58.33 !$ & 57,25 & $32.38 !$ & 47,25 \\
\hline
\end{tabular}


III. táblázat. Klaszterenkénti összefoglaló táblázat ( $N=5475)$.

A zárójelekben lévő számok a rangsort jelölik.

\begin{tabular}{|c|c|c|c|c|c|c|c|c|}
\hline \multirow[b]{2}{*}{ Klaszter } & \multirow{2}{*}{$\begin{array}{c}\text { Soha nem } \\
\text { dohányzott } \\
(\%)\end{array}$} & \multicolumn{2}{|c|}{ Fizikai aktivitás } & \multicolumn{2}{|c|}{ Alvás } & \multirow{2}{*}{$\begin{array}{l}\Psi \text {-szomatika } \\
\text { (átlag pont) }\end{array}$} & \multirow{2}{*}{$\begin{array}{l}\text { Háttááás } \\
(\%)\end{array}$} & \multirow{2}{*}{$\begin{array}{c}M A ́ Q \text { (átlag } \\
\text { pont) }\end{array}$} \\
\hline & & $\begin{array}{c}\begin{array}{c}\text { Közlekedés } \\
(\%)\end{array} \\
\text { (1) }\end{array}$ & $\begin{array}{c}\text { Sport (átlag } \\
\text { pont) }\end{array}$ & $\begin{array}{l}\text { Ébredés friss } \\
(\%)\end{array}$ & OSAS (\%) & & & \\
\hline $1(16)$ & $12(5)$ & $55(7) !$ & $8.97 \quad(3)$ & $0(4)$ & $68(13)$ & $-0.906(16)$ & $27(15)$ & $1.76(16)$ \\
\hline 2 (8) & $0(7)$ & $0(12)$ & (1) & $100(1)$ & \begin{tabular}{|ll}
94 & $(5)$
\end{tabular} & $-0.227 \quad(4)$ & $70 \quad(5)$ & $2.31 \quad(6)$ \\
\hline $3 \quad(12)$ & $100(1)$ & $\begin{array}{ll}47 & (9) !\end{array}$ & $8.85 \quad(5)$ & $100(1)$ & $85(10)$ & $-0.361(13)$ & $54(12)$ & $2.20(11)$ \\
\hline $\begin{array}{ll}4 & (9) \\
\end{array}$ & $0(7)$ & $80 \quad(5)$ & 8.49 (9) & $100(1)$ & $91 \quad(6)$ & -0.270 & $\begin{array}{ll}66 & (7)\end{array}$ & $\begin{array}{|ll|}2.26 & (9) \\
\end{array}$ \\
\hline $5(15)$ & $39(6)$ & $37(10)$ & $\begin{array}{ll}0 & (12) \\
\end{array}$ & $90(3)$ & 84 (11) & $-0.352(12)$ & $50(13)$ & $2.14(13)$ \\
\hline $6 \quad(6)$ & $100()$. & 0 (12) & $8.43(11)$ & $100(1)$ & $\begin{array}{|ll|}95 & (5)\end{array}$ & $\begin{array}{|ll|}-0.257 & \text { (5) }\end{array}$ & 65 (8) & $2.39 \quad(2)$ \\
\hline $7 \quad(4)$ & $100(1)$ & $0(12)$ & 12 & $99(2)$ & $\begin{array}{|ll|}97 \quad(2) \\
\end{array}$ & $-0.224 \quad(3)$ & $79 \quad(1)$ & $\begin{array}{|ll|}2.30 & (7) \\
\end{array}$ \\
\hline $8(11)$ & $67(2) !$ & 3 (1) & $8.46(10)$ & $100(1)$ & $\begin{array}{|ll|}87 & (8)\end{array}$ & $-0.342(11)$ & $58(11)$ & $2.33 \quad(5)$ \\
\hline $\begin{array}{ll}9 & (1) \\
\end{array}$ & $100(1)$ & $87 \quad(2)$ & (1) & $100(1)$ & $\begin{array}{|ll|}96 & (2) \\
\end{array}$ & -0.182 (1) & $76 \quad(2)$ & $\begin{array}{|ll|}2.54 \quad(1) \\
\end{array}$ \\
\hline $10 \quad(2)$ & $53(3) !$ & $83 \quad(4)$ & $9.81 \quad(2)$ & $99(2)$ & \begin{tabular}{|ll}
95 & $(4)$ \\
\end{tabular} & $-0.285 \quad(9)$ & $63 \quad(9)$ & $2.20(11)$ \\
\hline $11 \quad(3)$ & $100(1)$ & $87 \quad(2)$ & $8.55 \quad(8)$ & $100(1)$ & $\begin{array}{|ll|}98 & (2) \\
\end{array}$ & $\begin{array}{|ll|}-0.268 & (7) \\
\end{array}$ & $71 \quad(4)$ & $\begin{array}{|ll|}2.36 & (3) \\
\end{array}$ \\
\hline $12(5)$ & $0(7)$ & $90 \quad(1)$ & (1) & $100(1)$ & $\begin{array}{|ll|}96 & (3) \\
\end{array}$ & -0.219 (2) & 72 (3) & $2.33 \quad(4)$ \\
\hline $13 \quad(7)$ & $0(7)$ & $86 \quad(3)$ & $8.61 \quad(7)$ & $100(1)$ & \begin{tabular}{|ll}
98 & $(2)$ \\
\end{tabular} & $-0.286(10)$ & 69 (6) & $2.18(12)$ \\
\hline $14(10)$ & $0(7)$ & $0(12)$ & $8.49 \quad(9)$ & $100(1)$ & $\begin{array}{|ll|}91 & (3) \\
\end{array}$ & $\begin{array}{lll}-0.266 & (6) \\
\end{array}$ & $59(10)$ & $\begin{array}{|ll|}2.27 \quad(8) \\
\end{array}$ \\
\hline $15(13)$ & $52(4) !$ & 57 (6)! & $8.91 \quad(4)$ & $0(4)$ & \begin{tabular}{|ll}
86 & $(8)$
\end{tabular} & $-0.638(15)$ & $46(14)$ & $2.00(15)$ \\
\hline $16(14)$ & $0(7)$ & 49 (8)! & $8.67 \quad(6)$ & $100(1)$ & $80 \quad(5)$ & $-0.368(14)$ & $54(12)$ & $2.13(14)$ \\
\hline Átlag & $47.07 !$ & $47.42 !$ & 9.01 & 95.02 & 91.71 & -0.341 & 61.20 & 2.21 \\
\hline
\end{tabular}

egészségben eltöltött időt nyerhetnek. Kiválasztható az az egészségmagatartási faktor, aminek megváltoztatásával a legnagyobb egészségügyi hozadékot tudjuk elérni a katonáknál.

\section{Irodalom}

[1] Belloc, N.B. and Breslow, L.: Relationship of Physical Health Status and Health Practices. Preventive Medicine, 1972, 1: 409-421.

[2] Ornish, D., Scherwitz, L.W., Billings, J.H. et al.: Intensive Lifestyle Changes for Reversal of Coronary Heart Disease. JAMA, 1998, 280(23):

[3] Hayat, S.A, Luben, R., Keevil, V.L. et al.: Cohort Profile: A prospective cohort study of objective physical and cognitive capability and visual health in an ageing population of men and women in Norfolk (EPIC-Norfolk 3). International Journal of Epidemiology, 2014, 43:1063-1072. DOI:10.1093/ije/dyt086

[4] Walsh, R.: (2011) Lifestyle and Mental Health American Psychologist, 2011, 66(7): 579 -592. DOI: $10.1037 / \mathrm{a} 0021769$
[5] Berrington, G.: Body-Mass Index and Mortality among 1.46 Million White Adults. N. Engl. J. Med., 2010, 363(23): 2211-2219.

[6] McCrory, M.A., Campbell, W.W.: Effects of eating frequency, snacking, and breakfast skipping on energy regulation: symposium overview. J. Nutr., 2011,141(1):144-7. DOI: 10.3945/jn.109.114918.

[7] Belinova, L., Kahleova, H., Malinska, H. et. al.: The effect of meal frequency in a reducedenergy regimen on the gastrointestinal and appetite hormones in patients with type 2 diabetes: A randomised crossover study PLoS One. 2017, 12(4): e0174820.

[8] U. S. Department of Health and Human Services. The Surgeon General's report on nutrition and health. DHHS (PHS) Publication, 1988, 88:50210. Washington, DC: U.S. Government Printing Office.

[9] World Health Organization Global Healthy diet, Fact sheet $\mathrm{N}^{\circ} 394$ Updated September 2015. http://www.who.int/mediacentre/factsheets/fs394/en/ 
[10] Torjesen, T.: Cycling to work has substantial health benefits, study finds. BMJ 2017; 357 https://doi.org/10.1136/bmj.j1944 (Published 20 April 2017) Cite this as: BMJ, 2017, 357:j1944

[11] Sótér A.: A Magyar Honvédség egészségkockázati térképe, a személyi állomány egészségmagatartásának helyőrségi különbségei.Hadmérnök, 2009, 4(3):

[12] World Health Organization Global recommendations on physical activity for health 2010. ISBN: 9789241599979

[13] Netzer, N.C., Stoohs, R.A., Netzer, C.M., et al.: Using the Berlin Questionnaire to identify patients at risk for the sleep apnea syndrome. Ann. Intern. Med.,1999, 131 (7):485-91.

[14] Hornyák B., Ördögh Istvánné: Prevalence of Obstructive Sleep Apnea Syndrome (OSAS) in the HDF military personnel I. The clinical, psychological and military significance of the OSAS, (Hungarian). Hadtudományi Szemle, 2015, 8(2): 99-111.

[15] Szilágyi Zs., Csukonyi Cs., Sótér A., Hornyák B.: 2014 The introduction of mental staminatesting steps in the matter of the Hungarian Defense Forces. (Hungarian) Hadtudományi Szemle, 2014, 7(1) 158-178.

[16] Hornyák B.: The relationship between mental stamina of health behavior (Hungarian). Honvédorvos, 2012, 64(3-4): 129-143.

[17] Kroenke, K.1., Spitzer, R.L., Williams, J.B.: The PHQ-15: Validity of a new measure for evaluating the severity of somatic symptoms. Psychosom. Med., 2002, 64(2):258-66.

[18] Kocalevent et al.: Standardization of a screening instrument (PHQ-15) for somatization syndromes in the general population. BMC, Psychiatry, 2013, 13:91. DOI:10.1186/1471244X-13

[19] Novák A., Hornyák B., Rázsó Zs. et al.: Predicting how health behaviours contribute to the development of diseases within a military population in the Hungarian Defence Forces. J.R. Army Med. Corps, 2018, 164(2): 107-111.

\section{Capt. A. Novák PhD, Lt.Col. Andrea Sótér PhD}

\section{Military health profile in the Hungarian Defence Forces}

Living in the age of chronic noncommunicable diseases - also in the military - the focus is on maintaining health and preventing diseases. The health status, which is the base of longterm deployability, is mostly determined by lifestyle which can be examined by analyzing individual health behavior factors. Our research was carried out with using the data of the prevention questionnaire taken in the occupational health screening among the military personnel of the Hungarian Defense Forces. We sought to find out which health behavior patterns are typical of the military members and whether these patterns are significantly differentiated homogeneous groups, so-called clusters. First, we assigned value scales to the selected 24 objective and subjective health behavior factors, which followed by hierarchical cluster analysis. As a result of our research, we identified 16 health profiles that are homogeneous in terms of health behaviors. They can serve as a basis for further development of prevention programs and can improving the health status of the military personnel.

Key-words: prevention, health behavior, clusteranalyses, military health profil

Dr. Novák Attila szds., PhD 1134 Budapest, Róbert Károly krt. 44. 